\title{
BUDGETING FORMULATION OF IRRIGATION'S OPERATION AND MAINTENANCE COST IN INDONESIA BASED ON AREA INDEX AND STRUCTURE INDEX
}

\author{
Sutarto Edhisono $^{1 *}$, Sri Sangkawati Sachro ${ }^{1}$, Iwan K. Hadihardaja ${ }^{2}$ and Suripin ${ }^{1}$ \\ ${ }^{1}$ Civil Engineering Department, Faculty of Engineering, Diponegoro University, \\ Semarang 50239, Indonesia \\ ${ }^{2}$ Center of Water Resources Development, Bandung Institute of Technology, \\ Bandung 40116, Indonesia \\ *edhisono@live.undip.ac.id
}

\begin{abstract}
This study analyzes the difference of Operation \& Maintenance $(O \& M)$ costs between government's budgeting method and an alternative approach using Analytical Hierarchy Process (AHP). The AHP was used to determine the formula of budget distribution by considering irrigation infrastructure, location of irrigation area. The formulation was calculated based on the observation to samples in West Java, Central Java and East Java, three provinces that have significant agricultural contributions in Indonesia. Irrigation areas characteristics assessed were areas, channels, weirs and hydraulic structures. The result shows that the equation had an exceptional different linier relationship compared with the quadratic relation equation. They were far more reasonable having a linier proportionality between the budget and the amount of infrastructure. The conclusion also integrates with the linier relationship. Thus, while the precise equation are not intended to be universal applicable, the most important finding was how $O \& M$ budget was correlated positively to the amount of infrastructure, not only depending on the area of irrigation.
\end{abstract}

Keywords - Irrigation; Operation and maintenance; Analytic Hierarchy Process

\section{INTRODUCTION}

Indonesia is an agricultural country whereby the majority of population works as farmers and thus depending deeply on agriculture [1], With rice field area of 8,112,103 ha [2], the responsibility or authority are divided into three responsibility holders namely the central, provincial and district/city governments. Central government is responsible for $2,374,521$ ha of irrigation area. Now days, from the existing irrigation area, there are 734,820 ha of tertiary irrigation networks identified to be damaged [2-4]. Therefore, irrigation improvement is a priority for government to increase national food production, especially for rice. The cost for the maintenance of irrigation schemes in Indonesia requires great deal every year allocated from central and local governmental budget $[2$, 5]. However, these funds do not meet the requirements for the maintenance of irrigation schemes from each Irrigation Area (IA). Based on data from Direktorat Jenderal Bina Sumber Daya Air (Directorate General of Water Resources), the provision funds for irrigation management in 2006-2009 is amounted IDR 12,836 billion from central 
government, IDR 45,695 billion from province, and IDR 254,175 billion from the district. Fund for irrigation management is allocated only IDR 46,675 per ha. By those funds, irrigation only earn the number of fund about $\pm 25 \%$ from cost allocation policy of the Operation and Maintenance (O\&M) requirements which is about IDR 150,000 - IDR 250,000 per ha $[5,6]$.

Irrigation areas with higher productivity would be a priority for maintenance compared with structures at lower productivity [7,8]. One big structure with immense funding will spend most of funds for maintenance of some small structures requiring lower maintenance costs [9]. Another disproportion occurring that a large irrigation area with fewer structures will receive more maintenance funds than smaller irrigation areas with more dense buildings. Nevertheless, the urgency level of irrigation assets in wider irrigation areas is less urgent compared to a narrower irrigation area [10]. Operating irrigation systems needs substantial funds; government must allocate a substantial budget for O\&M irrigation systems [11, 12]. Currently, Indonesia government sets cost allocation $\mathrm{O} \& \mathrm{M}$ based on the large area of irrigation and it has not considered the level of the density of structure $[9,11,13,14]$, therefore it is possible cause the unbalanced of allocating in cross-irrigation areas. Unfairness in this case is that irrigation with large areas will receive more budget allocation despite having shorter maintenance channel and fewer structures. In contrast, small irrigation areas will receive little maintenance allocation even though the irrigation areas have longer channels with more structures. In fact, irrigation areas with longer channels and more structures, although small in size, will require more maintenance costs than the larger area having shorter channels and fewer structures. The large irrigation area with the minimum infrastructure may receive the budget more than its requirements, the other side, small irrigation area completed with higher number of infrastructures will get insufficient fund [15].

Based on this situation problem, a fair budgeting of $\mathrm{O} \& \mathrm{M}$ must be formulated in order to be sufficient the cost needs which is finally essential to maintain the productivity of agriculture. Hadihardaja and Grigg [16] conducted the study about index of budgeting toward the index structure in seven irrigation areas in West Java, with the wide range of irrigation area about 3000-9969 ha. Index of structure is the combination of the channel length and the number of irrigation building. This study result the equation of index budgeting as a function of index structure in the shape of non-linier. By the same method, the study developed again by Sachro, S. [17] by conducting the trials on eight samples of irrigation areas in Central Java to observe, whether the formulation from the first study can be applied in universal and unlimited only in West Java. The wide area of irrigation used is more variation which is 3,000-9,969 ha. From this second study, the equation of index budgeting as a function of index structure is a linier equation; therefore the equation cannot be used in universal.

A wide range of irrigation areas influence the level of intensiveness of structure, besides the difference equation in both of the studies, it is also needed to conducted reevaluation by entering the wide range of irrigation areas into the index structure. Therefore, this study presents budgeting formulation of irrigation's operation and maintenance cost in Indonesia based on area index and structure index. Using the same method, we apply on 12 samples of irrigation region in West, Central and East Java with the area between 100 ha -1000 ha. Further, we evaluate the correlation between index of budgeting and index of infrastructure can be applied in the region involved.

\section{PROPOSED METHOD}

Developing system of the management water resources in principle related to taking decision. In the case of irrigation management, related to variation of structures, the wide range of irrigation, irrigation channel. This chapter present the elaboration of multi- 
criteria of decision analysis, the alternatives used, followed by defining the criteria used and formulation budgeting.

\subsection{MULTI-CRITERIA DECISION ANALYSIS}

Multi-criteria decision analysis (MCDA) is to finding the best answer or alternative solution among many alternatives based on preference of decision maker under more evaluation from one criteria of evaluation, the result from the process of MCDA is a comparison value among each alternatives [18]. In this study, the method of MCDA used is Analytic Hierarchy Process (AHP).

The AHP is an analysis method multi-criteria which is created by mathematician Saaty in 1970s [19], to help taking decision for completing the process of decision maker by examining the coherent and logical preference. This method can be used in qualifying the criteria of qualitative through its weighting. This method is able to identify and consider the inconsistent of decision maker.

The AHP has been successful applied in various fields [20-23]. This method has been used frequently for irrigation-related study field [11,24-28]. AHP is also applied to water pricing to improve water quality [29]. But, the topic on using AHP to determine the irrigation O\&M budget was first proposed by Hadihardaja and Grigg [16].

Formulating the hierarchical structure in using AHP method is an important step in analyzing the problem, therefore giving more details on hierarchical is very important to have the ability of analytic and a good thinking. If the analysis gives unsatisfied result or the matrix is declared inconsistent, it means this method possible us to change the input or add the other criteria. Hierarchical structure is to determine the hierarchical tree from three levels where its aim is on the top level, selection criteria is on medium level and alternative criteria is on lower level. The level of hierarchical related each other [19]. The next step is the comparison in pairs from the various elements of hierarchical by combining the logical thinking and experience. This matrix is used to evaluate the relative interest from one element which is related each other by using the appropriate scale.

\subsection{CHOOSING ALTERNATIVES AND CRITERIA}

Irrigation areas which become an authority of the government receive the budget based on its wide. The alternative in this study is twelve irrigation areas which are in West Java, Central Java and East Java with the wide range of area about 100-1000 ha, as described in Table I. Irrigation area in West Java under the authority of Public Works Service of Water Resources, in Central Java is under authority of Public Works Service of Water Resources and Spatial and in East Java is irrigation area which is under the authority of Public Works Service of Water Resources.

These three provinces have the contribution which is significant in agriculture in Indonesia. For rice sector, BPS (Central Bureau of Statistics) noted that West Java has 925,042 ha of rice field, Central Java has 952,525 ha of rice field and East Java has $1,102,863$ ha of rice field in 2013 [3]. The combination of the tree regions contribute 36. $74 \%$ from the total of rice field in Indonesia. From this data, it is clear that the agriculture (especially rice production) in west, central and east java is very important for Indonesia.

Moreover, four criteria used to evaluate twelve alternatives are areas, channel length, weir and hydraulic structure which are described in Table I. The criteria of the number hydraulic structure show the number of structure for tapping structure and structure for tapping in each area in 2015. The criteria of channel length are primary channel and secondary channel. 
Table I. Name of Irrigation Area, Area, Weir, Channel Length, and Hydraulic Structure

\begin{tabular}{|c|l|c|r|r|r|r|}
\hline No. & $\begin{array}{c}\text { Name of } \\
\text { Irrigation Area }\end{array}$ & $\begin{array}{c}\text { Area } \\
\text { Code }\end{array}$ & $\begin{array}{c}\text { Area } \\
\text { (ha) }\end{array}$ & $\begin{array}{c}\text { Number of } \\
\text { Weir }\end{array}$ & $\begin{array}{c}\text { Channel } \\
\text { Length } \\
(\mathbf{K M})\end{array}$ & $\begin{array}{c}\text { Number of } \\
\text { Hydraulic } \\
\text { Structure }\end{array}$ \\
\hline 1 & Cipurut & CIP & 349.0 & 4 & 4.239 & 17 \\
\hline 2 & Depok & DEP & 429.6 & 1 & 9.552 & 19 \\
\hline 3 & Cigasong & CIG & 788.0 & 7 & 28.149 & 76 \\
\hline 4 & Cisalada & CIS & 604.0 & 1 & 5.101 & 10 \\
\hline 5 & Padas Klorot & PDK & 701.0 & 1 & 6.950 & 52 \\
\hline 6 & Sidopangus & SID & 719.0 & 2 & 12.270 & 22 \\
\hline 7 & Bumiayu & BUM & 220.0 & 1 & 4.100 & 5 \\
\hline 8 & Kramat & KRA & 163.0 & 1 & 3.000 & 7 \\
\hline 9 & Taji & TAJ & 986.0 & 1 & 11.772 & 11 \\
\hline 10 & Jaten Emas & JAT & 197.0 & 1 & 5.724 & 9 \\
\hline 11 & Gandon Terik & GAN & 612.0 & 1 & 5.684 & 8 \\
\hline 12 & GumboloDawuhan & GUM & 275.0 & 1 & 5.698 & 12 \\
\hline \multicolumn{2}{|c|}{ Total } & 6043.6 & 22 & 102.239 & 248 \\
\hline
\end{tabular}

\subsection{FORMULATION BUDGETING FOR OPERATING AND MAINTENANCE OF IRRIGATION}

Optimal budgeting strategy for each irrigation region can be determined based on the equation $B_{i}=L_{i} P_{I C i}+H i P_{H s i}$ [23]. In this study determined based on the equation (1) below:

$$
B_{i}=L_{i} P_{I C i}+H_{i} P_{H S i}+A_{i} P_{I A i}+W_{i} P_{W i}
$$

Where $B_{i}$ is budgeting index for area area $i, P_{I c i}$ is channel index of weir for area $i, D_{H s i}$ is Hydraulic structure index for area $i, D_{\text {Iai }}$ is index of irrigation area for area $i$ and $D_{w i}$ is index of weir for area $i$. The $D_{I c i}, D_{H s i}, D_{I a i}$ and $D_{W i}$ can be presented respectively in equations (2), (3), (4) and (5) as follow:

$$
\begin{aligned}
& D_{I C i}=\frac{L_{i}}{\sum_{i=1}^{N} L_{i}} \\
& D_{H S i}=\frac{H_{i}}{\sum_{i=1}^{N} H_{i}} \\
& D_{I A i}=\frac{A_{i}}{\sum_{i=1}^{N} A_{i}} \\
& D_{W i}=\frac{W_{i}}{\sum_{i=1}^{N} W_{i}}
\end{aligned}
$$

Equation 1 is applied instead of using the budget allocation related to average fare for all irrigation regions $\bar{B}$. In addition, $B i$ depends on the four decision variables such as $P_{I C}$, $P_{H S}, P_{I A}$ and $P_{W i}$ that are optimized based on the minimum variance. The four variables of $B$ and $B i$ have the same unit in rupiahs per hectare. The model can be verified by using the equation 6 below that is equal to the total budget planned for selected irrigation regions:

$$
\bar{B} A=\sum_{i=1}^{N} B_{i} a_{i} .
$$

\section{RESULT AND DISCUSSION}

\subsection{BUDGETING INDEX, CALCULATED WITH EQUATION}

This study use four variables including wide range of irrigation area, total of weir, total of structure and total of channel length. The derivative of $P_{I c i}$ and $P_{H s i}$ can be referred to study from Hadihardaja and Grigg [16]. After several steps, these variables will be 
converted into budgeting index (symbolize with $B_{I i}$ ) by equation 8 and the value is illustrated in Figure 1.

$$
\begin{aligned}
& y=0.225 x+0.0085 \\
& B_{I i}=0.225\left(P_{I A i}+P_{I C i}+P_{W i}+P_{H S i}\right)+0.0085
\end{aligned}
$$

The $B_{I i}$ is budgeting index for area $i, P_{I a i}$ is large of index for area $i$ which defining as $D_{I A i} P_{I a i}\left(P_{I a i}\right.$ assumed as 1$), P_{I C}$ is channel index for area $i$ which defining as $D_{I C i} P_{I c i}\left(P_{I c i}\right.$ assumed as 1), $P_{H s i}$ is index of hydraulic structure for area $i$ defining as $D_{H S i} P_{H s i}\left(P_{H s i}\right.$ assumed as 1), and $P_{W i}$ is index of weir for area $i$ defining as $D_{W i} P_{W i}\left(P_{W i}\right.$ assumed as 1$)$. Based on those equations, the value of budgeting index for twelve areas can be illustrated in Figure 2.

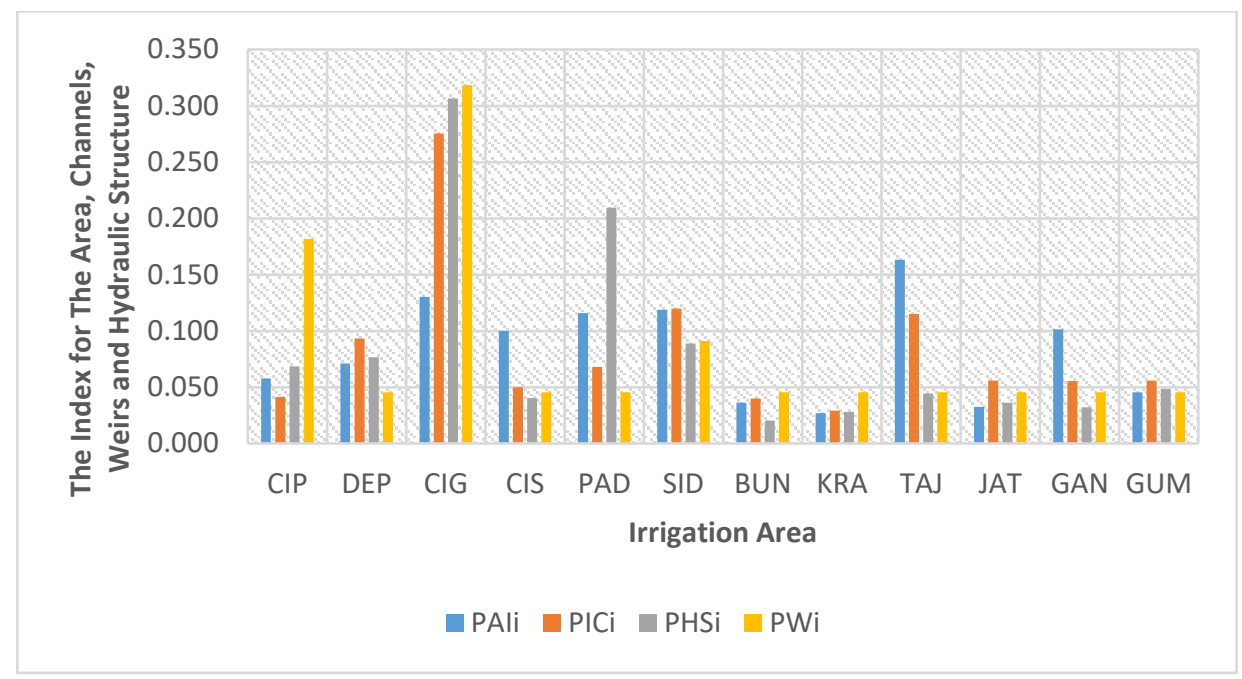

Fig. 1 The value of $P_{A I i}, P_{I C i}, P_{H s i}$ and $P_{W i}$ for each Irrigation area

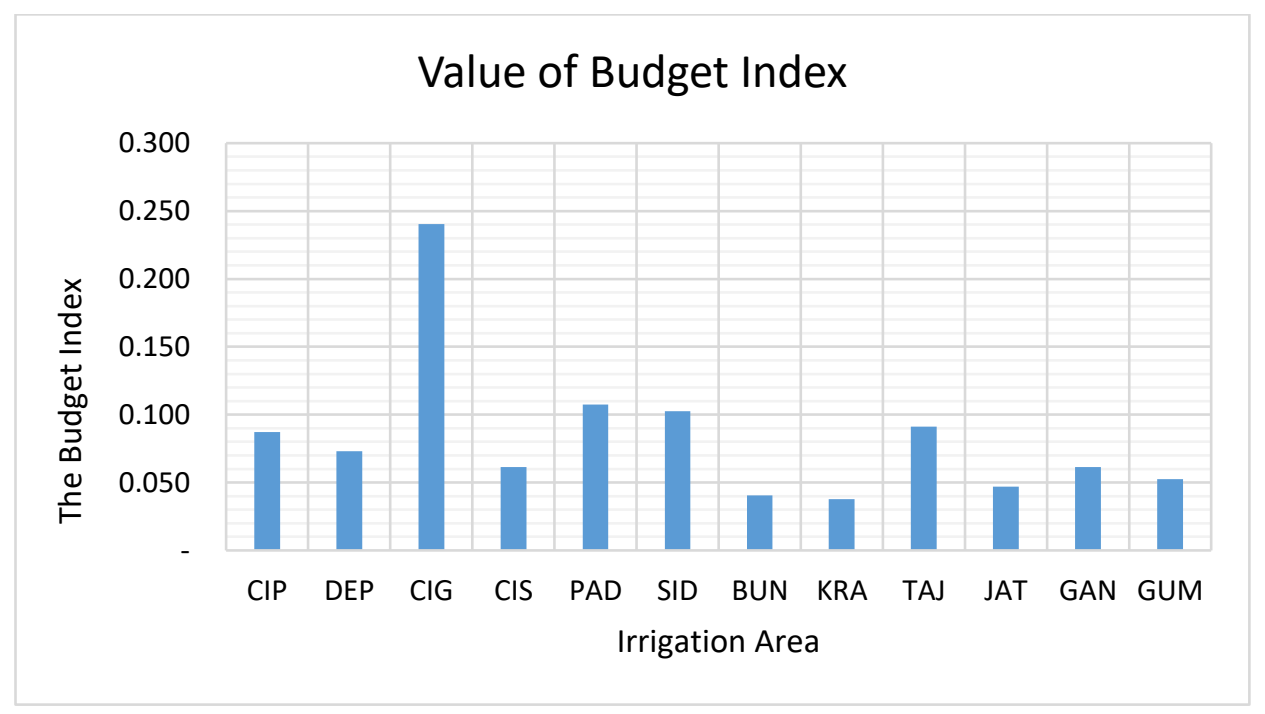

Fig. 2 The value of budgeting index per irrigation area

\subsection{THE BUDGETING INDEX CALCULATED WITH THE AHP METHOD}

For calculating AHP, its aim is determined by using the wide area, the number of weir, channel length, and hydraulic structure as criteria. As the beginning, it is assumed that 
four criteria have the same priority for AHP. Matrices for each criterion are respectively showed in Tables II, III, IV, and V.

Table II. Pairwise value for the Irrigation Area criteria

\begin{tabular}{lllllllllllll}
\hline & CIP & DEP & CIG & CIS & PAD & SID & BUM & KRA & TAJ & JAT & GAN & GUM \\
\hline CIP & 1,000 & 1,231 & 2,258 & 1,731 & 2,009 & 2,060 & 1,586 & 2,141 & 2,825 & 1,772 & 1,754 & 1,269 \\
DEP & & 1,000 & 1,834 & 1,406 & 1,632 & 1,674 & 1,953 & 2,636 & 2,295 & 2,181 & 1,425 & 1,562 \\
CIG & & & 1,000 & 1,305 & 1,124 & 1,096 & 3,582 & 4,834 & 1,251 & 4,000 & 1,288 & 2,865 \\
CIS & & & & 1,000 & 1,161 & 1,190 & 2,745 & 3,706 & 1,632 & 3,066 & 1,013 & 2,196 \\
PAD & & & & & 1,000 & 1,026 & 3,186 & 4,301 & 1,407 & 3,558 & 1,145 & 2,549 \\
SID & & & & & & 1,000 & 3,268 & 4,411 & 1,371 & 3,650 & 1,175 & 2,615 \\
BUM & & & & & & 1,000 & 1,350 & 4,482 & 1,117 & 2,782 & 1,250 \\
KRA & & & & & & & 1,000 & 6,049 & 1,209 & 3,755 & 1,687 \\
TAJ & & & & & & & & & 1,000 & 5,005 & 1,611 & 3,585 \\
JAT & & & & & & & & & 1,000 & 3,107 & 1,396 \\
GAN & & & & & & & & & & & 1,000 & 2,225 \\
GUM & & & & & & & & & & & 1,000 \\
\hline
\end{tabular}

Table III. Pairwise value for the Weirs criteria

\begin{tabular}{lllllllllllll}
\hline & CIP & DEP & CIG & CIS & PAD & SID & BUM & KRA & TAJ & JAT & GAN & GUM \\
\hline CIP & 1,000 & 4,000 & 1,750 & 4,000 & 4,000 & 2,000 & 4,000 & 4,000 & 4,000 & 4,000 & 4,000 & 4,000 \\
DEP & & 1,000 & 7,000 & 1,000 & 1,000 & 2,000 & 1,000 & 1,000 & 1,000 & 1,000 & 1,000 & 1,000 \\
CIG & & & 1,000 & 7,000 & 7,000 & 3,500 & 7,000 & 7,000 & 7,000 & 7,000 & 7,000 & 7,000 \\
CIS & & & & 1,000 & 1,000 & 2,000 & 1,000 & 1,000 & 1,000 & 1,000 & 1,000 & 1,000 \\
PAD & & & & & 1,000 & 2,000 & 1,000 & 1,000 & 1,000 & 1,000 & 1,000 & 1,000 \\
SID & & & & & & 1,000 & 2,000 & 2,000 & 2,000 & 2,000 & 2,000 & 2,000 \\
BUM & & & & & & 1,000 & 1,000 & 1,000 & 1,000 & 1,000 & 1,000 \\
KRA & & & & & & & 1,000 & 1,000 & 1,000 & 1,000 & 1,000 \\
TAJ & & & & & & & & & 1,000 & 1,000 & 1,000 & 1,000 \\
JAT & & & & & & & & & 1,000 & 1,000 & 1,000 \\
GAN & & & & & & & & & & & 1,000 & 1,000 \\
GUM & & & & & & & & & & & & \\
\hline
\end{tabular}

Table IV. Pairwise value for the Channel Length criteria

\begin{tabular}{lllllllllllll} 
& CIP & DEP & CIG & CIS & PAD & SID & BUM & KRA & TAJ & JAT & GAN & GUM \\
\hline CIP & 1,000 & 2,253 & 6,640 & 1,203 & 1,640 & 2,895 & 1,034 & 1,413 & 2,777 & 1,350 & 1,341 & 1,344 \\
DEP & & 1,000 & 2,947 & 1,873 & 1,374 & 1,285 & 2,330 & 3,184 & 1,232 & 1,669 & 1,681 & 1,676 \\
CIG & & & 1,000 & 5,518 & 4,050 & 2,294 & 6,866 & 9,383 & 2,391 & 4,918 & 4,952 & 4,940 \\
CIS & & & & 1,000 & 1,362 & 2,405 & 1,244 & 1,700 & 2,308 & 1,122 & 1,114 & 1,117 \\
PAD & & & & & 1,000 & 1,765 & 1,695 & 2,317 & 1,694 & 1,214 & 1,223 & 1,220 \\
SID & & & & & & 1,000 & 2,993 & 4,090 & 1,042 & 2,144 & 2,159 & 2,153 \\
BUM & & & & & & 1,000 & 1,367 & 2,871 & 1,396 & 1,386 & 1,390 \\
KRA & & & & & & & 1,000 & 3,924 & 1,908 & 1,895 & 1,899 \\
TAJ & & & & & & & & & 1,000 & 2,057 & 2,071 & 2,066 \\
JAT & & & & & & & & & 1,000 & 1,007 & 1,005 \\
GAN & & & & & & & & & & 1,000 & 1,002 \\
GUM & & & & & & & & & & & 1,000 \\
\hline
\end{tabular}


Table V. Pairwise value for the HydraulicStructures criteria

\begin{tabular}{|c|c|c|c|c|c|c|c|c|c|c|c|c|}
\hline & CIP & DEP & CIG & CIS & PAD & SID & BUM & KRA & TAJ & JAT & GAN & GUM \\
\hline CIP & 1,000 & 1,118 & 4,471 & 1,700 & 3,059 & 1,294 & 3,400 & 2,429 & 1,545 & 1,889 & 2,125 & 1,417 \\
\hline DEP & & 1,000 & 4,000 & 1,900 & 2,737 & 1,158 & 3,800 & 2,714 & 1,727 & 2,111 & 2,375 & 1,583 \\
\hline CIG & & & 1,000 & 7,600 & 1,462 & 3,455 & 15,200 & 10,857 & 6,909 & 8,444 & 9,500 & 6,333 \\
\hline CIS & & & & 1,000 & 5,200 & 2,200 & 2,000 & 1,429 & 1,100 & 1,111 & 1,250 & 1,200 \\
\hline PAD & & & & & 1,000 & 2,364 & 10,400 & 7,429 & 4,727 & 5,778 & 6,500 & 4,333 \\
\hline SID & & & & & & 1,000 & 4,400 & 3,143 & 2,000 & 2,444 & 2,750 & 1,833 \\
\hline BUM & & & & & & & 1,000 & 1,400 & 2,200 & 1,800 & 1,600 & 2,400 \\
\hline KRA & & & & & & & & 1,000 & 1,571 & 1,286 & 1,143 & 1,714 \\
\hline TAJ & & & & & & & & & 1,000 & 1,222 & 1,375 & 1,091 \\
\hline JAT & & & & & & & & & & 1,000 & 1,125 & 1,333 \\
\hline GAN & & & & & & & & & & & 1,000 & 1,500 \\
\hline GUM & & & & & & & & & & & & 1,000 \\
\hline
\end{tabular}

The value in the matrices above is based on the ratio between two irrigation areas which is suitable. For example, on the top left in Table II above have the value 1.231 which is derivate by divide the DEP area with CIP. This process is repeated to all of location. All of available components, each priority of location can be calculated by AHP method and the value listed in Table VI below.

Table VI. The values of the infrastructure ratio, the budget distribution, and the budget allocation which are derived by AHP method

\begin{tabular}{ccccccc}
\hline & & & \multicolumn{2}{c}{ RATIO } & & AHP \\
\cline { 2 - 7 } CODE & AREA & CHANNEL & WEIR & $\begin{array}{c}\text { HYDRAULIC } \\
\text { STRUCTURE }\end{array}$ & TOTAL & GOAL \\
DEP & 0.058 & 0.041 & 0.182 & 0.069 & 0.350 & 0.069 \\
CIG & 0.071 & 0.093 & 0.045 & 0.077 & 0.287 & 0.079 \\
CIS & 0.130 & 0.275 & 0.318 & 0.306 & 1.030 & 0.234 \\
PAD & 0.100 & 0.050 & 0.045 & 0.040 & 0.236 & 0.066 \\
SID & 0.116 & 0.068 & 0.045 & 0.210 & 0.439 & 0.119 \\
BUM & 0.119 & 0.120 & 0.091 & 0.089 & 0.419 & 0.108 \\
KRA & 0.036 & 0.040 & 0.045 & 0.020 & 0.142 & 0.036 \\
TAJ & 0.027 & 0.029 & 0.045 & 0.028 & 0.130 & 0.031 \\
JAT & 0.163 & 0.115 & 0.045 & 0.044 & 0.368 & 0.105 \\
GAN & 0.033 & 0.056 & 0.045 & 0.036 & 0.170 & 0.041 \\
GUM & 0.101 & 0.056 & 0.045 & 0.032 & 0.235 & 0.066 \\
TOTAL & 0.046 & 0.056 & 0.045 & 0.048 & 0.195 & 0.048 \\
\hline
\end{tabular}

Table VI. Continued

\begin{tabular}{|c|c|c|c|c|c|c|}
\hline & BUM & KRA & TAJ & JAT & GAN & GUM \\
\hline \multirow{3}{*}{$\begin{array}{c}\mathbf{P}_{\mathrm{IAi}}+\mathbf{P}_{\mathrm{ICi}}+\mathbf{P}_{\mathrm{Wi}}+\mathbf{P}_{\mathrm{HSi}} \\
\text { BudgetDistributionby } \\
\text { AHP } \\
\text { Budgetingindexby } \\
\text { AHP }\left(\mathbf{B}_{\mathrm{Ii}}\right)\end{array}$} & 0.14 & 0.13 & 0.37 & 0.17 & 0.24 & 0.195 \\
\hline & 0.036 & 0.031 & 0.105 & 0.041 & 0.066 & 0.048 \\
\hline & 0.040 & 0.038 & 0.091 & 0.047 & 0.061 & 0.052 \\
\hline
\end{tabular}


Table 6. Continued

\begin{tabular}{ccccccc}
\hline & BUM & KRA & TAJ & JAT & GAN & GUM \\
\hline $\mathbf{P}_{\text {IIi }}+\mathbf{P}_{\text {ICi }}+\mathbf{P}_{\mathrm{Wi}}+\mathbf{P}_{\mathrm{HSi}}$ & 0.14 & 0.13 & 0.37 & 0.17 & 0.24 & 0.195 \\
$\begin{array}{c}\text { BudgetDistributionby } \\
\text { AHP }\end{array}$ & 0.036 & 0.031 & 0.105 & 0.041 & 0.066 & 0.048 \\
$\begin{array}{c}\text { Budgetingindexby } \\
\text { AHP }\left(\mathbf{B}_{\mathrm{Ii}}\right)\end{array}$ & 0.040 & 0.038 & 0.091 & 0.047 & 0.061 & 0.052 \\
\hline
\end{tabular}

All of available component from each location can be calculated by using AHP method and listed value in Table VIII. The weight of priority can be converted to be budgeting index which is adjusted with the infrastructure ratio $\left(P_{I A i}+P_{I C i}+P_{W i}+P_{H S i}\right)$ and the correlation among thus are showed on the Table VI above, and the plot between the infrastructure ratio and its respective budgeting index is depicted in Figure 3.

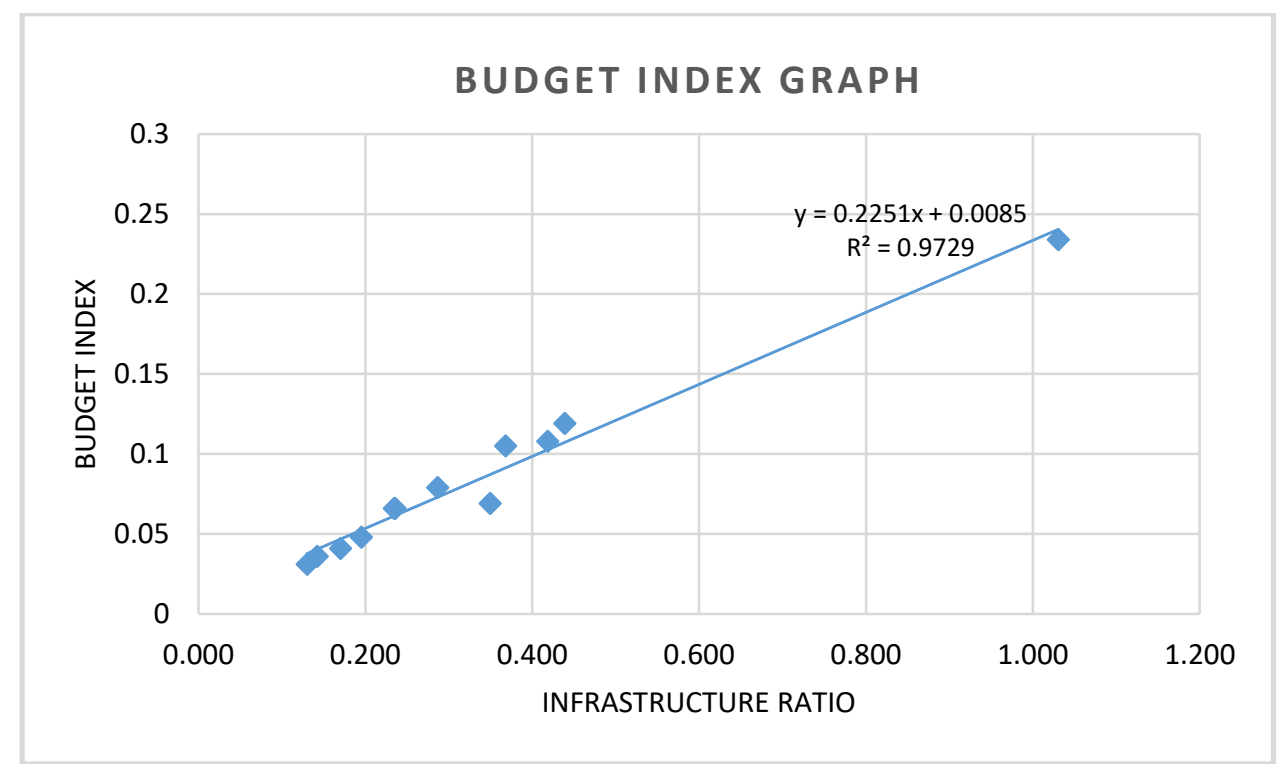

Fig. 3 The plot between the infrastructure ratio and its respective budgeting index

By assuming the budgeting $\mathrm{O} \& \mathrm{M}$ is IDR 450,000/ ha, then the comparison of government allocated fund is showed in Figure 4 below. Meanwhile based on formulation budgeting index with the formula of in (9), the result obtained as illustrated in Table VII below: 


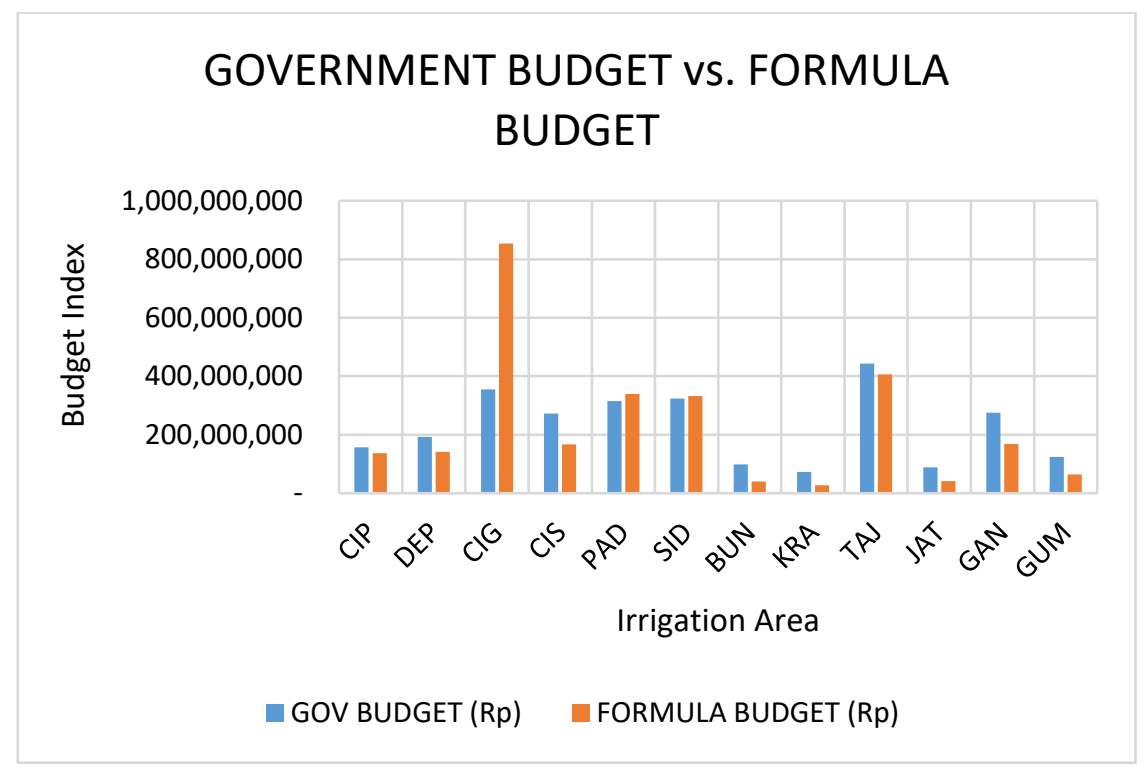

Fig. 4 The comparison of government allocated fund and the formulation by assuming budgeting O \& M IDR 450,000/ha

Table VII. The formulation budgeting index by assuming budgeting O \& M IDR 450,000.-/ha

\begin{tabular}{ccc}
\hline CIP & $\begin{array}{c}\text { GOV BUDGET } \\
\text { (IDR) }\end{array}$ & $\begin{array}{c}\text { FORMULA BUDGET } \\
\text { (IDR) }\end{array}$ \\
\hline DEP & $157,050,000$ & $137,051,379$ \\
CIG & $193,320,000$ & $141,265,027$ \\
CIS & $354,600,000$ & $853,316,769$ \\
PAD & $271,800,000$ & $167,401,717$ \\
SID & $315,450,000$ & $338,906,578$ \\
BUM & $323,550,000$ & $332,665,451$ \\
KRA & $99,000,000$ & $40,121,577$ \\
TAJ & $73,350,000$ & $27,722,538$ \\
JAT & $443,700,000$ & $405,716,928$ \\
GAN & $88,650,000$ & $41,560,879$ \\
GUM & $275,400,000$ & $168,974,614$ \\
& $123,750,000$ & $64,916,543$ \\
\hline
\end{tabular}

Budgeting $\mathrm{O} \& \mathrm{M}$ for Cigasong (CIG) irrigation area based on government is amounted IDR 354,600,000, while based on the formulation of budgeting index based on AHP is about IDR 853,316,769. This case happened because of the large of area which about 788 ha and the number of hydraulic structure which about 76 . Comparing with Taji Irrigation area, based on the government budgeting $\mathrm{O} \& \mathrm{M}$ which is amounted IDR $443,700,000$, while based on the formulation of budgeting index based on AHP is about IDR 405,716,928 despite the large of irrigation area of Taji is bigger than that Cigasong, but in the case of hydraulic structure, Taji has 11 number of hydraulic structure, while Cigasong has 76 number of hydraulic structure. It showed that the number of hydraulic structure determine the budgeting of $\mathrm{O} \& \mathrm{M}$ compared with the large of irrigation area. The formulation above if compared with the result of previous study by Hadihardaja with 
3000 ha- 9000 ha of area for four irrigation areas in West Java which obtained the equation (10) below.

$B_{I i}=7.42\left(P_{I C i}+P_{H S i}\right)^{2}-1.19\left(P_{I C i}+P_{H S i}\right)+0.5$

Equation (10) which is formulated by Hadihardaja and Grigg [16] based on AHP method for case study in west java, evaluated for various irrigation areas in Central Java. If it is applied directly (that means it use the value of same variable), it did not produce satisfied result because of the lower of new budgeting $\left(N B_{i}\right)$. It implies that the value will be low if it did not consider the aspect of infrastructure sufficiently into the calculation. Thus equations are modified again by Sachro S [17] with 3,000-32,000 ha of area with the criteria of large irrigation area, channel length and the number of structure for eight irrigation areas in central java which obtain the equation (11) below.

$$
B_{I i,}=1.5675\left(P_{I C i}+P_{H S i}\right)+0.045
$$

The result of Sachro S [17] Work show the relation of linier is found more realistic to be applied. The relation of linier is also found in this study which obtain the equation (12) as can be seen below:

$$
B_{I i}=0.225\left(P_{I A i}+P_{I C i}+P_{W i}+P_{H S i}\right)+0.0085
$$

It is logic that budgeting $\mathrm{O} \& \mathrm{M}$ must increase or decrease linearly and it is relative toward the number of infrastructure. Both of equation is linier, but it has different shape such as illustrated in Figure 5.

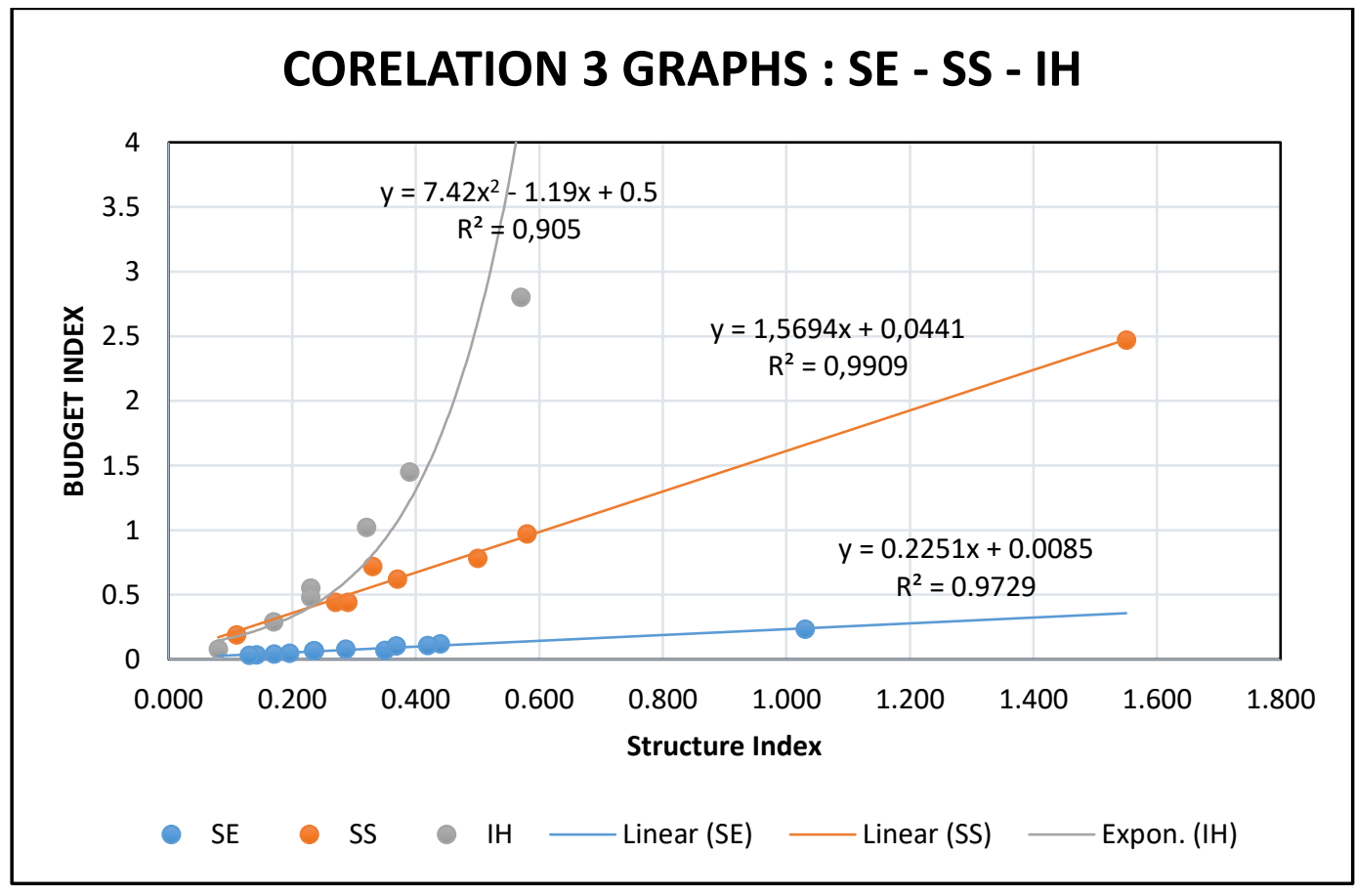

Fig. 5 Relation Budget Index dan Stucture Index [16,17]

Finally, it can be concluded that the coefficient for the equation will be different depending on the situation and the condition of investigated area. However, the form of equation obtained tends to be linier combined with the form of quadratic. 


\section{CONCLUSION}

This study has determined the budget of $\mathrm{O} \& \mathrm{M}$ with the method of AHP for various agriculture in province of West Java, Central Java and East Java, Indonesia. The next point is the conclusion of this study: the cost of budgeting $\mathrm{O} \& \mathrm{M}$ for irrigation depends on the characteristic of infrastructure irrigation such as large area, the number of weir, channel length, and hydraulic structure. The cost of $O \& M$ for irrigation tends appropriate in linier with the amount of irrigation infrastructure. Linier function is different from the conclusion of the previous study which gives quadratic function as a result. It can be said that proportionality linier is more logic because the budgeting will increase or decrease linearly with the amount of infrastructure and not quadratic. Each region has characteristic its own budget therefore there is not equation or single function applicable in universal. Because of the different conclusion related with the relation must be linier or quadratic, it needs more investigation to understand the condition which underlies the use both of the function.

\section{REFERENCES}

[1] Hidayah Z.,"Ensiklopedi suku bangsa di Indonesia", Yayasan Pustaka Obor Indonesia, (2015).

[2] Pertanian K., "Rencana Strategis Kementerian Pertanian Tahun 2015-2019", Jakarta (ID): Kementerian Pertanian, (2015).

[3] Pertanian K., "Statistik Lahan Pertanian Tahun 2009-2013", Jakarta: Pusat Data dan Sistem Informasi Pertanian, (2014).

[4] Pertanian P.S.E.D.K., "Rencana Strategis Pusat Sosial Ekonomi dan Kebijakan Pertanian Tahun 20152019".

[5] Air D.J.S.D. and K.P. Umum, "36\% Jaringan Irigasi Rusak, Ini Rincian Perbaikan dan Pembangunan PU, (2014).

[6] Bank W., "World Bank Open Data", (2014).

[7] Lipton M., J. Litchfield, and J.-M. Faurès, "The effects of irrigation on poverty: a framework for analysis", Water Policy. 5(5-6), (2003): 413-427.

[8] Matson P.A., W.J. Parton, A. Power, and M. Swift, "Agricultural intensification and ecosystem properties", Science. 277(5325), (1997): 504-509.

[9] Soentoro E.A., F.I. Rohmat, and V. Vurnamawati, "Fair Budgeting Formulation for O\&M of Irrigation Using Multi-Criteria Decision Analysis: WA and AHP Methods", Journal of Civil Engineering. 21(1), (2014): 1-12.

[10] Hussain I. and M.A. Hanjra, "Irrigation and poverty alleviation: review of the empirical evidence", Irrigation and Drainage, 53(1), (2004): 1-15.

[11] Anjasmoro B. and S. Sangkawati, "Priority Analysis of Small Dams Construction using Cluster Analysis, AHP and Weighted Average Method Case Study: Small Dams in Semarang District", Procedia engineering, 171, (2017): 1514-1525.

[12] Carswell G., "Agricultural intensification and rural sustainable livelihoods: a'think piece'", (1997).

[13] Hadihardaja I.K., "Rural Infrastructure Policy Development: Irrigation and Water Resources Sector Final Report", Collaboration Between Coordinating Ministry of Economic Affairs, Gajah Mada University, and the Technical Assistance Management Facility, Jakarta. (2005).

[14] Hadihardaja I.K., D. Indrawati, Y. Suryadi, and I. Soekarno, "Budgeting Strategy and Sensitivity Analysis for Irrigation Infrastruture Maintenance", Jogjakarta: International Committee on Irrigation and Drainage, (2010).

[15] Hagos F., G. Makombe, R.E. Namara, and S.B. Awulachew, "Importance of irrigated agriculture to the Ethiopian economy: Capturing the direct net benefits of irrigation", Vol. 128. IWMI, (2009).

[16] Hadihardaja I.K. and N.S. Grigg, "Decision support system for irrigation maintenance in Indonesia: a multi-objective optimization study", Water Policy, 13(1), (2011): 18-27.

[17] Sachro S.S., V. Kurniawan, J. Hadihardaja, and I.K. Hadihardaja4, "Evaluating The Budgeting Approach of Operation and Maintenance of Irrigation in Indonesia by Using Analytic Hierarchy Process", Accepted to be published at Agricultural Engineering International: CIGR Journal, (2018).

[18] Baker D., D. Bridges, R. Hunter, G. Johnson, J. Krupa, J. Murphy, and K. Sorenson, "Guidebook to decision-making methods", Developed for the Department of Energy USA", no. January, Washington DC, (2001).

[19] Saaty T., "What is the analytic hierarchy process?. InMathematical models for decision support 1988 (pp. 109-121)", Springer Berlin Heidelberg, (1988).

[20] Ramos A., L. Cunha, and P.P. Cunha, "Application de la Méthode de l'Analyse Multicritère Hiérarchique à l'étude des glissements de terrain dans la région littorale du centre du Portugal: Figueira da Foz-Nazaré", Geo-Eco-Trop. 38(1), (2014): 33-44. 
[21] Kumar M., A. Suresh, and K. Subramanaya, "Application of an analytical hierarchy process to prioritize the factors affecting ERP implementation", International Journal of Computer Applications, 2(2), (2010): 1-6.

[22] Tacnet J.-M., "Prise en compte de l'incertitude dans l'expertise des risques naturels en montagne par analyse multicritères et fusion d'information", Ecole Nationale Supérieure des Mines de Saint-Etienne, (2009).

[23] Gallic B.L., S. Mardle, and J. Boncoeur, "Les objectifs d'une politique publique vus par les acteurs: une analyse multicritères de la politique commune de la pêche", Économie publique/Public economics, (16), (2006).

[24] Karami E., "Appropriateness of farmers' adoption of irrigation methods: The application of the AHP model", Agricultural systems, 87(1), (2006): 101-119.

[25] Montazar A. and S. Behbahani, "Development of an optimised irrigation system selection model using analytical hierarchy process", Biosystems engineering, 98(2), (2007): 155-165.

[26] Montazar A. and E. Zadbagher, "An analytical hierarchy model for assessing global water productivity of irrigation networks in Iran", Water resources management, 24(11), (2010): 2817-2832.

[27] Anane M., L. Bouziri, A. Limam, and S. Jellali, "Ranking suitable sites for irrigation with reclaimed water in the Nabeul-Hammamet region (Tunisia) using GIS and AHP-multicriteria decision analysis", Resources, Conservation and Recycling. 65, (2012): 36-46.

[28] Bencheikh A., A. Nourani, and M.N. Chabaca, "Sustainability evaluation of agricultural greenhouse structures in southern of Algeria using AHP, case of study: Biskra province", Agricultural Engineering International: CIGR Journal, 19(1), (2017): 56-64.

[29] Sachro S.S., I.K. Hadihardaja, and J. Hadihardaja, "Cost Sharing and Water Pricing to Improve River Water Quality", International Journal of Waste Resources (IJWR), (2013). 